\title{
The Effect of Self Efficacy on Burnout Mediated by Stress Among Kindergarten Teachers in Indonesia
}

\author{
Deliana Sri Maryati \\ Faculty of Education, Semarang State University,Indonesia \\ maryatideliana@mail.unnes.ac.id
}

\begin{abstract}
The objective of this study is to investigate the effect of stress variable as a mediating role between self efficacy on burnout. Likert scale questionnaires were distributed to a sample of 60 kindergarten teachers who have not been certified in Gunungpati area, using purposive sampling data collection technique. Partial test and the bootstrapping analysis by SPSS 20 were applied. The results show that there is a significant effect between self efficacy on stress. There is also a significant effect between self efficacy and stress on burnout. Stress is shown to have influence as a mediate role on the relationship between self efficacy and burnout, this is indicated by $t$ value of bootstrapping test (3.352) $>t$ table $(-2.000)$. The research concludes that self efficacy has negative correlation and plays an important role in the onset of stress and burnoutt.
\end{abstract}

Keywords: Self-Efficacy, Stress, Burnout, Kindergarten Teacher

\section{INTRODUCTION}

Every organization has its own goal. To achieve it, this organization should be supported by some factors. Human factor is the most dominant in achieving the goal as expected by this organization from both welfare and readiness aspect. Human resources factors in education term are headmaster, teachers, students, and administrators. In this case, teachers play important roles for student achievement. It has been confirmend by the prior research finding that the qualities of the teacher-student relationship predict children's successful school adjustment [1]. It has been proved in the reseach by Like other education level in general, in kindergarten school instructional achievement is dominantly determined and influenced by the teachers.

A teacher is the pioneer in education both formal and non formal one. Being a kindergaten teacher is not easy thing to do. It needs specific and proffesional skills where not every one can handle it [2]. Furthermore the goverment through National Education Ministry tries to optimize teacher's role by demanding some requirement that should be fulfilled by kindergarten teachers [3]

Rahman [4] explained that teacher as profession requires high communication skill to other people especially

\author{
Pramudhita Ghia Mustika \\ Faculty of Education, Semarang State University,Indonesia
}

to students. This impacts to his or her behaviour in facing learning situation. Since how hard the requirement to be a teacher, it sometimes creates many troubles relating to teaching learning situation, one of them is burnout. Many kindergarten teachers feel that their job as teachers are so heavy. They often feel desparated in managing their students, hopeless, and easy to give up in facing schooling problems. They confess that the content of curriculum is so heavy and they are demanded to make daily educational report. In delivering material to their students, they are demanded to be creative and innovative. The job stress faced by the kindergarten teachers are the early indicators that they suffer from burnout. [5] Yet, It is not all teacher suffering job stress would experience burnout. The self-efficacy beliefs for each of the three domains are significantly and negatively related to the depersonalisation and emotional exhaustion dimensions of burnout, and significantly positively related to the personal accomplishment dimension [.6..].

Burnout is one's respond to cronical emotional tension dealing with other person, especially whenever he or she has a problem. The high level of burnout suffered by a teacher influences to either work performance or health. If a teacher can't carry out his or her duty proffessionally and effectivelly, instructional goal can't be achieved. It indicates that it is important for a teacher to minimize burnout symptom. So he or she can perform well and instructional goal can be achieved [7].

One factor how to minimize burnout is that stress should be well managed. Stress is the impact of one's justification, where he or she justifies whether the teacher has sufficient empowerment to cover the environment demands [8]. Long term stress leads to depression and if it is not properly handled, burnout syndrom will emerge, emotional condition where someone feels physically bored which tends his or her performance will dicrease as the consequence of the increasing of work demand. But if the stress is soon overcome, it will not last long [4]. An important factor that can overcome stress felt by some teachers is self efficacy.

Bandura declared that self efficacy was individual's belief relating to one's competence in carrying out some duties so that the aim targetted can be achieved. Self-efficacy has been studied in terms of its ability to predict academic success, academic self-efficacy accounted for $11 \%$ to $14 \%$ of 
variance in academic performance and persistence. It means, those mostly likely to withdraw from a nursing program had low academic self-efficacy [.9..]. Self efficacy generated motivation, cognitive skill and reduced emotional action and tension which were needed in coping situational demand. So individual with low self efficacy tended to be less adaptive in facing certain problem or duty. Only teacher with low self efficacy tends to burnout [1].

Bandura added that the reaction to one's stress occurrred because of one's low self efficacy to control any threat coming from inconvenient environment. So if he or she faced unexpected situation, he or she could not react well. Furthermore, self-efficacy and dispositional optimism partially weakened the relationship between stress and suicidal ideation [10].

Teachers having high self efficacy were able to manage accademical stress by coping every problem they had.

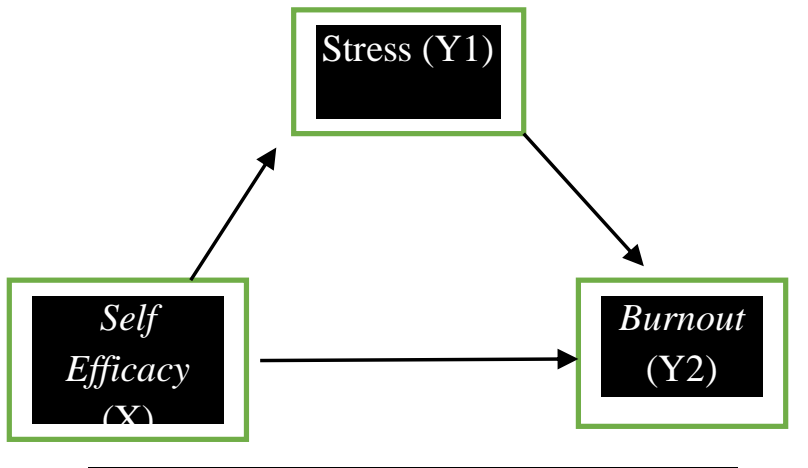

Picture 1. Research design

\section{RESEARCH OBJECTIVE}

\section{To identify the effect of self-efficacy on burnout mediated by stress}

\section{RESEARCH METHOD}

Population of the research was 90 kindergarten teachers. The research used purpisve sampling technique. Variables used in this research were self efficacy as independent variable, burnout as dependent variable, and stress as mediation variable. Burnout variable was meassured using scale based on Maslach . Stress variable was meassured using scale based on Taylor. Self efficacy was meassured using scale based on Bandura. Data analysis used t test and bootstapping and being supprted by SPSS, to see whether there was mediation role of stress. Try out of data instrument
But those having low self efficacy tried to avoid every accademical problem appeared. The importance of self efficacy in handling teachers's stress played an imprtant role in minimizing burnout symptom which might happened to kindergarten teachers. It showed that stress was a variable which mediated between self efficacy and burnout. Based on the explanation above, hypothesis could be set up as followed:

$\mathrm{H} 1$ : self efficacy influenced to stress among kindergarten teachers.

$\mathrm{H} 2$ : stress influenced to burnout among kindergarten teachers

H3: Self efficacy influenced to kindergarten teachers

H4: Stress mediated the influence of self efficacy to burnout of kindergarten teachers.

Based on the hypothesis above research modal developed could be seen in picture 1 .

was done before data analysis was done. $\mathrm{T}$ test also needed normality assumsion and heteroskedasticity data, so normality test was done using Kolmogorov-Smirnov, and heterokedasticity with glejser.

\section{RESULT AND DISCUSSION}

\section{Result of Tryout Validity}

The result of tryout validity using SPSS 20 program showed that 15 items were not valid, so these items were not used.

\section{Result of Tryout Reliability.}

Tryout reliability was done using Cronbach alpha (a). A construction or variable was considered reliable if it gave Cronbach alpha value >0,70. Result of tryout reliability of each variable was $>0,70$ so all research instrumentswas stated reliable.

\section{Result of Tryout normality}

Tryout normality aimed to test whether in regression model, the distructed variable or residual had normal distribution, as known that $\mathrm{t}$ and $\mathrm{F}$ tryout assumed that residual value followed normal distribution. If this assumsion didn't go as it was so tryout of statistics was not valid for some minor samples. The result of normality tryout with kolmogorov-Smirnov Test the value of Asymp sig (2-tailed) was $0,910>005$, so data distribution was catagorized normal. 


\section{Result of Heteroskedasticity Tryout}

At the result of output SPSS showed that all variables had sig value $\geq 0,05$ so regression model didn't contain heteroskedasticity.

\section{Bootstrapping Tryout}

Bootstrapping was an approach which didn't assume the form of variable distribution and could be applied at minor samples

In explaining the output of the script, some statements should be taken into account:

1. To notify how far the indirect influence of self-efficacy to burnout through stress, which was denoted from the value of indirect effect and significance using normal distribution, namely $-0,3731$.

2. To notify the significance of indirect influence which could be seen at Sig (two) of indirect effect and significance using normal distribution that was significance at 0,0059

3. To notify how far standard error bootstrapping that was indicated from i.e at bootstrap result for indirect effect that was 0,1113 .

4. To calculate the value of $\mathrm{t}$ calculation, the indirect influence of bootstrapping using formulation pattern: $\mathrm{t}$ calculation $=$ indirect effect valuel standard error bootstrapping.

$\mathbf{t}$ =indirect effect value / standar error
bootstrapping

The explanation was that the indirect effect of self efficacy (X) to burnout through stress (M), the range of indirect influence was $(-0,3731)$. The value of mediation coefficience $(-0,3731)$ was significant at $0,0059<0,05$. The conclusion was that mediation relation happened.

The result of bootsrapping gave estimated value of indirect effect of self efficacy to burnout through stress, standard error and the value of confidance level were $95 \%$ $99 \%$. So $t$ value of indirect influence using bootstrapping occurred.:

$$
\mathrm{t}=\mathbf{- 0 . 3 7 3 1} / \mathbf{0 . 1 1 1 3}=\mathbf{- 3 . 3 5 2}
$$

if $t$ calculation was found positive (+), so $t$ table also used positive value $(+)$ or hypothesis acceptance was on right side. And if $t$ table was found negative (-), so $t$ table should be negative (-) or hypothesis acceptance was on left side. Based on the calculation above, it was seen that $\mathrm{t}$ calculation had negative value (-) so $t$ table was also negative (-) or hypothesis acceptance was on left side.

Based on bootstrapping tryout $\mathrm{t}$ table was $-2,000$, which meant calculation value $(-3,352)>t$ table $(-2,000)$.

\section{DISCUSSION}

Based on the result of the research done, it proved that self efficacy influenced significantly to stress. It meant that self efficacy influenced the emerging stress among kindergarten teachers. It's like research from Hee-Sook Sim and Weon-Hee Moon (2015) that states. It proved that the hypothesis stated that there was significant influence of self efficacy to stress among kidergarten teachers was acceptable. Self efficacy of kindergarten teachers district was reflected from the belief based on duty handicap faced by them. Teachers having high self confidance felt sure that they could cover accademical duties with all they had. Those having high self belief were able to analyze level of duty handicap which one should be done and which one should be avoided. When the kindergarten teachers at Gunung pati district felt that their capability and competence were not strong enough to carry out the duties, they would easily suffer from stress at high level. The result of this research was in accordance to the research Pratiwi which indicated that there was correlation between self efficacy in writing final project and stress suffered by university students. Research on parenting was also revealed that parents who have good self efficacy would experience less stress [11].

The research result proved that stress had positive influence to burnout. It was indicated by value of $t$ calculation $12,77>\mathrm{t}$ table 2,00. It showed that stress suffered by kidergarten teachers influenced the emerging of burnout they experienced. When they suffered from stress which impacted to cognitive, physiological, emotional, and behaviour disturbance so they felt they were powerless, hopeless in doing their duties. All duties they had were to be the heavy burden to carry. It was in accordance with the research done by [14] which indicated that stress influenced to burnout experienced by elementary teachers in Spain.

The research also showed that self efficacy influenced to burnout. It was indicated by the value of $t$ calculation 4,657 > t table $-2,000$. It showed that self efficacy influenced to burnout experienced by kindergarten teachers. When they felt that they had less confidance to their competence they had, had less courage to accomplish their duties, they would easily suffer from burnout. The result of the research was apropriate with the research done by [8] which indicated that there was correlation between level of teachers' self efficacy and level of their burnout at inclusive shool in Surabaya. The higher level of self efficacy teachers had the less they suffered from burnout.

The bootstrapping calculation showed that the value of $t$ calculation was $(-3,352)>t$ table $(-2,000)$. It indicated that 
based on bootstrapping test, stress became variable of correlation mediation of self efficacy and burnout. It showed that the self efficacy of kindergaten teachers at Gunung Pati district undirectly brought about burnout. The forms of burnout might be fatiques, depersonalisation, degradation of self achievement relating to stress. Due to being lack of high self efficacy among kindergarten teachers seen from strength, level, and generality, the number of teachers suffering from stress increased significantly. It could be seen from their physical performance and their health, degradation of cocentration, work and achievement disorder, depression, job withdrawal and degradation of interpersonal relation quality. If teachers had such kinds of turbalances, it would impact to burnout they experienced. The more level of stress they had the more increase burnout they had would be. The research result was in accordance with the research done by Schwarzer and Hallum, [10] which showed that stress could be relation mediation of self efficacy and burnout.

\section{CONCLUSION AND SUGGESTION}

The conclusion of the research was that self efficacy was a dominant factor which influenced the degree of stress and burnout among kindergarten teachers. The higher self efficacy teachers had the lower stress they suffered and vice verse the the lower self efficacy teachers had, the higher level of stress and burnout they had. Stress was a factor forming low self efficacy to be burnout symptom.

Based on the research result, it was recommended the school strengthen teachers' self efficacy by joining training, seminar, up grading relating to how to manage teaching learning proccess so the teachers had broarder knowledge and skill to overcome teaching learning handicap which potentially created stress and burnout.

\section{REFERENCE}

[1] Baker, Jean A.; Grant,Sycarah;Morlock, Larissa, 2008. School Psychology Quarterly, Vol 23(1), 3-14

[2] Efendi, Rohmad. 2013. "Self Efficacy: Studi Indigenos pada Guru Bersuku Jawa". Dalam Journal of Social and Industrial Psychology. Volume 2 No 2. Fakultas Ilmu Pendidikan UNNES

[3] Latiana, Lita., Mukminin, Amirul., H, Sri Sulastri D. 2010. "Meningkatkan Kualitas Pembelajaran dengan Pendekatan Area di Taman Kanak-kanak Melalui Pengembangan Kemampuan Guru Bertanya Divergen. Fakultas Ilmu Pendidikan UNNES

[4] Rahman, Ulifiani. 2007. "Mengenal Burnout pada Guru". Dalam Lentera Pendidikan. Volume 10 No 2.

[5] Schwarzer, Ralf, dan Hallum S. 2008. "Perceived Teacher Self Efficacy as a Predictor of Job Stress and Burnout: Mediation Analyses. Dalam International Association of Applied Psychology. No 57. Hal 152-171.

[6] Will J. G. Evers, Andre' Brouwers and Welko Tomic*British Journal of Educational Psychology (2002), 72, 227-243 British Psychological Society

[7] Maslach, Christina. 2003. Burnout: The Cost of Caring.Englewood Cliffs,N.K. Prentice-Hall:ISHK
[8] Puspitasari,Dita Ayu dan Handayani M.M. 2014. Hubungan Tingkat Self Efficacy guru dengan Tingkat Burnout pada Sekolah Inklusif di Surabaya.Dalam Jurnal Psikologi Pendidikan dan Perkembangan . Volume 3 No 1. Fakultas Psikologi Airlangga Surabaya.

[9] Taylor, Shelley E. 1995. Health Psychology. Mc. Grow-Hill International Editions

[10] Hee-Sook Sim and Weon-Hee Moon. 2015. Indian Journal of Science and Technology, Vol 8(35),

[11] Jun Feng, Shusheng Li, Huawen Chen* Department of Emergency Medicine, Tongji Hospital, Huazhong University of Science and Technology, Wuhan, China

[12] Linda Bloomingfield and Sally Kendall, 2012, Jurnal of Primary Health and Care research \& Development Volume 13 isuue 4

[13] Bandura, Albert. 1977. "Self-efficacy: Toward a Unify Change". Dalam Psychological Review. Volume 84 No. 2. Hal: 191215.

[14] Betoret, Fernando Domenech. 2009. Self Efficacy, School Resources, Job Stressors and Burnout among Spanish, Primary and Secondary School Teachers: A Structural Equation Approach. Educational Psychology. Volume 29 No 1. Hal 45-68. Spain: Routledge

[15] Manullang, M. 2008. Manajemen Personalia. Yogyakarta: Gadjah Mada University Press

[16] Papalia, Diane E., Old, Sally Wendkos., Feldman, Ruth Duskin. 2008. Human Development (Psikologi Perkembangan). Jakarta: Kencana Prenada Media Group 